\title{
Filter bed systems treating domestic wastewater in the Nordic countries - Performance and reuse of filter media
}

\author{
Petter D. Jenssen ${ }^{\mathrm{a}, *}$, Tore Krogstad ${ }^{\mathrm{a}}$, Adam M. Paruch ${ }^{\mathrm{b}}$, Trond Mæhlum ${ }^{\mathrm{b}}$, Kinga Adam ${ }^{\mathrm{c}}$, \\ Carlos A. Arias ${ }^{d}$, Arve Heistad ${ }^{c}$, Lena Jonsson ${ }^{\mathrm{e}}$, Daniel Hellström ${ }^{\mathrm{e}}$, Hans Brix ${ }^{\mathrm{d}}$, \\ Markku Yli-Halla ${ }^{\mathrm{f}}$, Lasse Vråle ${ }^{\mathrm{c}}$, Matti Valve ${ }^{\mathrm{g}}$ \\ a Department of Plant and Environmental Sciences, Norwegian University of Life Sciences, Fougnerbakken 3, P.O. Box 5003, 1432 Aas, Norway \\ b Soil and Environment Division, Bioforsk - The Norwegian Institute for Agricultural and Environmental Research, Frederik A. Dahls vei 20,1432 Aas, Norway \\ c Department of Mathematical Sciences and Technology, Norwegian University of Life Sciences, P.O. Box 5003, 1432 Aas, Norway \\ d Department of Biological Sciences, University of Aarhus, Ole Worms Alle, Building 135, 8000 Århus, C, Denmark \\ e Stockholm Water Co., SE-106 36 Stockholm, Sweden \\ ${ }^{\mathrm{f}}$ Applied Chemistry and Microbiology, Environmental Soil Science, University of Helsinki, P.O. Box 27, 00014 Helsinki, Finland \\ ${ }^{g}$ Finish Environmental Institute, Mechelininkatu 34a, P.O. Box 140, 00251 Helsinki, Finland
}

\section{A R T I C L E I N F O}

\section{Article history:}

Received 6 January 2010

Received in revised form 1 July 2010

Accepted 2 July 2010

\section{Keywords:}

Onsite wastewater treatment

Biofilter, Light-weight aggregates

Treatment performance, Recycling of

phosphorus, Fertilizer effect

\begin{abstract}
A B S T R A C T
Nine filter beds have been constructed in the Nordic countries, Denmark, Finland, Norway and Sweden. Filter beds consist of a septic tank followed by an aerobic pre-treatment biofilter and a subsequent saturated flow grass-covered filter. Thus, filter beds are similar to subsurface flow constructed wetlands with pre-treatment biofilters, but do not have wetland plants with roots submerged into the saturated filter. All saturated filters contain Filtralite ${ }^{\circledR} \mathrm{P}$, a light-weight expanded clay aggregate possessing high phosphorus sorption capacity. The filter bed systems showed stable and consistent performance during the testing period of 3 years. Removal of organic matter measured as biochemical oxygen demand (BOD) was $>80 \%$, total phosphorus (TP) $>94 \%$ and total nitrogen (TN) ranged from 32 to $66 \%$. Effluent concentrations of fecal indicator bacteria met the European bathing water quality criteria in all systems. One system was investigated for virus removal and somatic viruses were not detected in the effluent. The investigations revealed that the majority of the BOD and nitrogen removal occurred in the pre-treatment filters and the phosphorus and bacteria removal was more prominent in the saturated filters. The saturated filters could be built substantially smaller than the current design guidelines without sacrificing treatment performance. The used filter material met the Norwegian regulations for reuse in agriculture with respect to heavy metals, bacteria and parasites. When saturated with phosphorus, the light-weight aggregate, Filtralite ${ }^{\circledR} \mathrm{P}$ used in the saturated bed is a suitable phosphorus fertilizer and additionally has a liming effect.
\end{abstract}

(c) 2010 Elsevier B.V. All rights reserved.

\section{Introduction}

In the rural areas of the Nordic countries, there are many homes and recreational facilities where the use of conventional centralised sewer systems becomes very expensive due to topography and long distances between the connected facilities. In addition, soil conditions (Heistad et al., 2001) and new stringent local regulations (Brix and Arias, 2005) limit the use of traditional onsite septic tank-soil infiltration systems. Small-scale conventional systems (package treatment systems), usually activated sludge or rotating biological contactors with chemical precipitation, are alternatives,

\footnotetext{
* Corresponding author. Tel.: +47 6496 5443/9137 7360; fax: +47 64965601.

E-mail address: petter.jenssen@umb.no (P.D. Jenssen).
}

but current investigations show that they have difficulties in meeting the discharge limits for phosphorus especially (Yri et al., 2007; Johannessen et al., 2008). Therefore, there is a need for robust low maintenance onsite systems with high treatment performance.

Subsurface flow constructed wetlands (CWs) with pretreatment biofilters for Nordic climate conditions have been pioneered in Norway (Jenssen et al., 1993). These CWs show excellent performance (Jenssen et al., 2005), but occupy a relatively large area compared to the package treatment plants. Due to the size and the use of phosphorus-sorbing (P-sorbing) light-weight aggregate (LWA), Filtralite ${ }^{\circledR} \mathrm{P}$, the investment cost of CWs becomes high. If the wetland plants were substituted by grass, the systems could be hidden under the lawn and if the subsurface flow filter could be made smaller the initial costs would be lower. This would greatly enhance the market potential in the Nordic countries. 




Fig. 1. General layout of the filter bed system: 1 - septic tank, 2 - pump well, 3 aerobic biofilter, 4 - subsurface horizontal flow filter bed, 5 - outlet well.

Wetland plants can enhance nitrogen (Zhu, 1998) and pathogen (Decamp et al., 1999) removal. On the other hand, phosphorus sorption sites may be blocked by organic matter or the sorption may be reduced by competitive sorption of organic anions or metal complexation (Nilsson, 1990; Guppy et al., 2005). Hence, vegetation may have both positive and negative effects with respect to treatment performance. This is also pointed by other authors (Mitsch et al., 2005; Sartoris et al., 2000; Thullen et al., 2005; Vymazal, 2005). Brix (1990) found that the ability of macrophytes to provide oxygen was limiting nitrification in horizontal subsurface flow CWs. In Norway, where plants are dormant during the cold season this has been overcome by using an aerobic biofilter (pre-treatment filter) preceding the horizontal subsurface flow wetland filter (Jenssen et al., 1993). The use of LWA with well-defined properties has simplified design of these treatment systems (Mæhlum and Jenssen, 2002; Jenssen and Krogstad, 2002). Therefore, the most frequently used filter media in such systems in the Nordic countries currently is LWA (Søvik and Kløve, 2005).

It is a goal in Nordic countries to reclaim and recycle phosphorus (P) from wastewater (SEPA, 2003). Kvarnström et al. (2004), found that the Filtralite ${ }^{\circledR} \mathrm{P}$, which has a high P-sorption capacity, could be used as a complementary phosphorus fertilizer provided its quality with respect to pathogens and heavy metals is acceptable for utilization in agriculture.

Supported by the Nordic Innovation Centre, the project "Wastewater treatment in filter beds" was initiated (Føllesdal, 2005). Participants from Denmark, Finland, Norway, and Sweden were involved. The main goals of the project were to evaluate the performance of full-scale filter bed systems, compare the performance of the unplanted filter beds to the more traditional CWs and investigate the possibilities for recycling of used filter media. This paper presents the key results from the Nordic project.

\section{Materials and methods}

\subsection{Study sites}

Three full-scale test/pilot plants have been constructed in Norway and two plants have been constructed in Denmark, Sweden and Finland, respectively. Each plant has the following components: a septic tank, a pump well, a vertical flow single pass aerobic biofilter, a subsurface horizontal flow filter and an outlet well (Figs. 1 and 2). Further specifications are shown in Table 1.

The biofilter consists of a $0.6 \mathrm{~m}$ deep filter of light-weight aggregate in the size range of $2-10 \mathrm{~mm}$. The filter and distribution system is either confined in a fibreglass tank the distribution system is fixed in a fibreglas hemisphere (dome) overlying the filter (Figs. 1 and 2 and Table 1). The distribution system consists of a high-pressure pump and a tangential fullconical nozzle centered in the dome above the biofiter. Details of the distribution system are given in (Heistad et al., 2001). The subsequent horizontal saturated filter contains LWA-Filtralite ${ }^{\circledR} \mathrm{P}$, an LWA especially developed for P-sorption in constructed wetlands. The saturation depth is con-

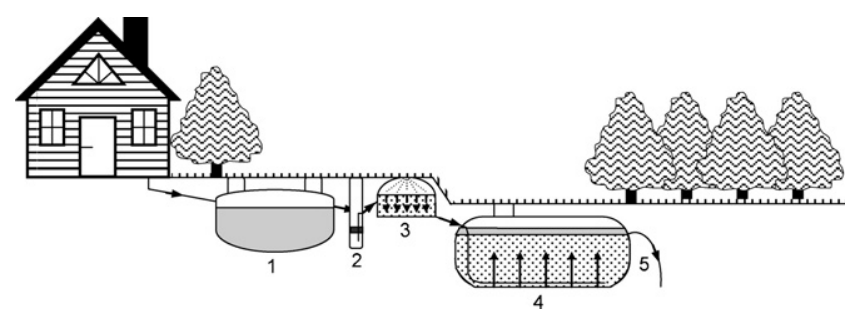

Fig. 2. Layout of the Norwegian compact filter system (N2): 1 - septic tank, 2 pump well, 3 - aerobic biofilter, 4 - upflow saturated filter tank, 5 - outlet.

trolled through the outlet well. The depth of the filter bed is $1.0 \mathrm{~m}$ and the current design volume is $40 \mathrm{~m}^{3}$ per household. Four systems (N2, N3, F2 and S1) had a more compact design N2 and F2 has vertical upflow filters confined in tanks of volumes 6 and $10 \mathrm{~m}^{3}$ respectively. The systems $\mathrm{N} 3$ and $\mathrm{S} 1$ had smaller horizontal flow filters of, respectively, 20 and $25 \mathrm{~m}^{3}$ (Table 1). In Denmark, recycling from the filter bed to the pre-treatment filter was practiced for the systems (D1, D2). The saturated filters are covered by grass and termed filter beds, but they could also be planted with wetland vegetation and termed constructed wetlands. The systems were monitored with monthly samples over 2 to maximum 3 years.

\subsection{Water sampling and analysis}

Water samples (except for the Swedish treatment plants) were all taken as grab samples from the septic tank effluent, the outlet of the biofilter, and the outlet of the filter bed. At the Swedish plants (S1, S2), composite samples were taken by flow controlled automatic samplers, placed after septic tanks and biofilters, and additionally at plant S1 also after the filter bed.

The samples were analyzed for organic matter (BOD), nitrogen forms $\left(\mathrm{NO}_{3}{ }^{-}, \mathrm{NO}_{2}{ }^{-}, \mathrm{NH}_{4}{ }^{+}\right)$, total phosphorus (TP) and faecal indicator bacteria. TN was computed as the sum of $\mathrm{NO}_{3}{ }^{-}, \mathrm{NO}_{2}{ }^{-}$, and $\mathrm{NH}_{4}{ }^{+}$. Virus indicators (somatic coliphages) were analyzed in the effluent from the Norwegian compact filter systems N2 only.

All physical-chemical analyses of water samples were performed on unfiltered samples by accredited laboratories in Norway, Denmark, Sweden and Finland. The national standards and common methods for each physical-chemical parameter were used.

The numbers of samples vary between the different systems and the different parameters. This makes a statistical comparison of the results difficult. However, experience has shown that systems as in this paper have a very low variation in effluent water quality (Jenssen et al., 2005) and thus a few samples can still characterize the performance of the system.

\subsubsection{Analyses of bacteria and viruses in water samples}

Thermotolerant coliform bacteria (TCB) and E. coli were determined by the multiple-tube fermentation technique following the standard method for detection and enumeration of coliforms (APHA, 1989). The enterococci were analyzed according to the Finnish standard SFS 3015 (1985). The analysis was started within $24 \mathrm{~h}$ of the sampling.

Analysis of viruses (somatic coliphages) in water samples was conducted as presence/absence tests. Samples with host culture were incubated overnight at $37^{\circ} \mathrm{C}$, allowing present somatic coliphages to multiply. Undiluted samples were applied on agar plates that were previously soaked in E. coli C host culture (Allestam and Carlander, 2000). The plates had a confluent host growth after $18 \mathrm{~h}$ of incubation at $37^{\circ} \mathrm{C}$. The positive control, applied with untreated wastewater and $\varphi \mathrm{X} 174$, had clear zones where the sample drops were applied, showing that the assay was working. 
Table 1

Specification of the nine test systems.

\begin{tabular}{|c|c|c|c|c|c|c|c|c|c|}
\hline \multirow[t]{2}{*}{ System specification } & \multicolumn{3}{|l|}{ Norway } & \multicolumn{2}{|c|}{ Denmark } & \multicolumn{2}{|l|}{ Finland } & \multicolumn{2}{|l|}{ Sweden } \\
\hline & N1 & $\mathrm{N} 2$ & N3 & D1 & $\mathrm{D} 2$ & $\mathrm{~F} 1$ & $\mathrm{~F} 2$ & $\mathrm{~S} 1^{\mathrm{a}}$ & $\mathrm{S} 2$ \\
\hline Households no. & 2 & 2 & 2 & 1 & 1 & 1 & 2 & 2 & 2 \\
\hline Septic tank volume $\left(\mathrm{m}^{3}\right)$ & 7.0 & 7.0 & 7.0 & 2.0 & 2.0 & 4.0 & 4.0 & 6.0 & 6.0 \\
\hline Pre-filter type & Tank & Dome & Dome & Tank & Tank & Dome & Tank & Tank & Tank \\
\hline Pre-filter media (mm) & $\mathrm{NR}^{\mathrm{b}} 4-10$ & NR2-4 & NR2-4 & NR2-4 & NR2-4 & $\mathrm{NC}^{\mathrm{c}} 3-8$ & $\mathrm{NC} 3-8$ & NR2-4 & NR2-4 \\
\hline Pre-filter area $\left(\mathrm{m}^{2}\right)^{\mathrm{d}}$ & 7.0 & 3.4 & 3.4 & 6.5 & 6.5 & 6.3 & 4.5 & 3.5 & 3.5 \\
\hline Filter bed volume $\left(\mathrm{m}^{3}\right)^{\mathrm{d}}$ & 35.0 & 6.0 & 20.0 & 40.0 & 40.0 & 40.0 & 5.0 & 25.0 & 35.0 \\
\hline Filter bed media (mm) & $0-4$ & $0-4$ & $0-4$ & $0-4$ & $0-4$ & $0-4$ & $0.5-4$ & $0-4$ & $0-4$ \\
\hline
\end{tabular}

a Office + apartment

b NR - normal density round.

c NC - normal density crushed.

d Area or volume per household.

\subsection{Agricultural experiments}

Two pot experiments were carried out with different Filtralite ${ }^{\circledR} \mathrm{P}$ samples, in order to study the fertilizer effect of $\mathrm{P}$ accumulated in the filter material. The fine sand soil, used in the experiments, had a pH $\left(\mathrm{H}_{2} \mathrm{O}\right) 5.7$ and $1.9 \%$ organic $\mathrm{C}$ and was poor in plantavailable $P$. Three yields of Italian ryegrass were grown in $5 \mathrm{dm}^{3}$ pots in both experiments, with four replicates in each treatment. Pristine unused Filtralite ${ }^{\circledR} \mathrm{P}$ and $\mathrm{Ca}\left(\mathrm{H}_{2} \mathrm{PO}_{4}\right)_{2}$ were used as reference fertilizers. $\mathrm{Ca}\left(\mathrm{H}_{2} \mathrm{PO}_{4}\right)_{2}$ was applied at the same rate as supplied in the used filter material. Filtralite ${ }^{\circledR} \mathrm{P}$ samples taken from filter beds that were in operation, for one or two years only, were tested in one experiment and applied to soil at the rate of $80 \mathrm{mg} \mathrm{P} \mathrm{kg}^{-1}$ of soil on the basis of total $\mathrm{P}$ in the filter material. For another experiment, Filtralite ${ }^{\circledR} \mathrm{P}$ was saturated with $\mathrm{P}$ in the laboratory with $\mathrm{NaH}_{2} \mathrm{PO}_{4}$ solution and washed free of excess P. This material corresponded to P-saturated filter material from mature full-scale systems. In this experiment, $P$ additions ranged from 0 to $100 \mathrm{mg} \mathrm{P} \mathrm{kg}^{-1}$ of soil. The amount of P retained by the Filtralite ${ }^{\circledR} \mathrm{P}$ during the saturation was used as the basis of dosing of the filter material. Sufficient quantities of nitrogen $\left(200 \mathrm{mg} \mathrm{kg}^{-1}\right)$, potassium (140-200 $\mathrm{mg} \mathrm{kg}^{-1}$ ), magnesium (50 $\mathrm{mg} \mathrm{kg}^{-1}$ ) and micronutrients were applied to each yield so that P supply was the factor limiting growth.

\subsection{Analysis of the solid filter material}

\subsubsection{Total phosphorus}

Total $\mathrm{P}$ of the Filtralite ${ }^{\circledR} \mathrm{P}$ materials and the soil used in the pot experiment was determined in a $\mathrm{H}_{2} \mathrm{SO}_{4}-\mathrm{H}_{2} \mathrm{O}_{2}-\mathrm{HF}$ digest (Bowman, 1988). Phosphorus was also extracted with aqua regia (ISO, 1995b), ammonium lactate (Egner et al., 1960) and water. The lactate method is used in agronomic soil testing in Norway and Sweden. In water extraction, $1 \mathrm{~g}$ samples of the material were extracted with $60 \mathrm{ml}$ of deionized water for $18 \mathrm{~h}$. Phosphorus of the filter materials and the soil used in the pot experiment was also fractionated with a slightly modified Chang and Jackson method (Hartikainen, 1979; Zhu et al., 2003). In that sequential extraction procedure $0.5 \mathrm{M} \mathrm{NH}_{4} \mathrm{Cl}$ dissolves the most easily soluble fraction, and $0.5 \mathrm{M} \mathrm{NH}_{4} \mathrm{~F}, 0.1 \mathrm{M} \mathrm{NaOH}$ and $0.25 \mathrm{M} \mathrm{H}_{2} \mathrm{SO}_{4}$ are supposed to extract $\mathrm{P}$ bound by $\mathrm{Al}, \mathrm{Fe}$ and $\mathrm{Ca}$, respectively. All extractions, with few exceptions, were carried out with three or four replications. Plant material, grown in the pot experiment, was digested with concentrated $\mathrm{HNO}_{3}$. All determinations of $\mathrm{P}$ were carried out with inductively coupled plasma atomic emission spectrometer (ICP-AES). The neutralizing value of the filter materials was determined by dissolving 0.5 -g Filtralite ${ }^{\circledR} \mathrm{P}$ samples with $50 \mathrm{ml}$ of $0.5 \mathrm{M} \mathrm{HCl}$ and titrating the remaining acidity with $0.5 \mathrm{M}$ $\mathrm{NaOH}$.

\subsubsection{Hygiene parameters}

The following hygienic indicators were analyzed: thermotolerant coliform bacteria (TCB), viruses (somatic coliphages and F-RNA phages), and parasite eggs.

TCB were determined by the same method as water samples, but the analyses were conducted on diluted samples of finely grinded filter media. Thus the results were presented as TCB per gram (g) of total solids (TS) in the filter media. Contents of TS in the media samples were determined by weighing wet samples, drying in a forced ventilated oven at $105^{\circ} \mathrm{C}$ for $24 \mathrm{~h}$ and re-weighing the dry samples. TS was then measured as grams of substance of the dry matter in the wet weight sample.

For the propagation and detection of two virus indicators, FRNA phage MS2 and $\varphi$ X174, host strain Salmonella typhimurium (S.t) WG49 and Escherichia coli (E. coli) strain C ATCC 13706 were used, respectively. The analyses were conducted following the standard procedures for detection and enumeration of bacteriophages (ISO, 1995a; ISO, 2000). However, only single agar layer was applied to the pour plate and the spot test. Briefly on the pour plate test, $0.5 \mathrm{ml}$ of an overnight working culture of the host strain was inoculated into $50 \mathrm{ml}$ of pre-warmed broth. Tryptone-yeast extract-glucose broth (TYGB) was used for S.t WG49 and modified Scholtens' broth (MSB) was used for E. coli C. Inoculum cultures were incubated for $3 \mathrm{~h}$ at $37^{\circ} \mathrm{C}$ and then were added to the culture tubes containing examined sample (solution of $5 \mathrm{~g}$ filter material in $25 \mathrm{ml}$ of $0.5 \%$ Tween 80 in PBS) and semi-solid agar. Tryptone-yeast extract-glucose agar (TYGA) was used for S.t WG49 and modified Scholtens' agar (MSA) was used for E. coli C content of the culture.

Human parasite indicator-helminth eggs, mainly nematodes represented by Ascaris, were investigated. The investigation was carried out in a specialized laboratory at the Norwegian School of Veterinary Sciences. According to the procedure for isolation of helminth eggs, the samples under examination were incubated at $27^{\circ} \mathrm{C}$ for 4 weeks, and $100 \mathrm{~g}$ of material from each sample was investigated by microscopy. The procedure has been described in greater detail by Gjerde in Pierzo et al. (2004) and reviewed elsewhere (Paulsrud et al., 2004, 2006).

\section{Results and discussion}

The filter beds, both the compact ones and the normal sized, showed high average performance during the testing period (Table 2). The general performance trend was stable and showed little fluctuation as exemplified by the results of one of the systems (Fig. 3). The removal of organic matter improved the first 3-4 months and then stabilized (Fig. 3). The phosphorus removal shoved a very slow, but stable increase. This is consistent with earlier investigations of similar systems (Jenssen et al., 2005). 
Table 2

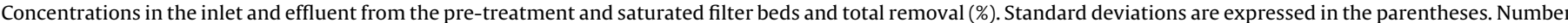
of samples evaluated $-n$.

\begin{tabular}{|c|c|c|c|c|c|c|c|c|c|}
\hline \multirow[t]{2}{*}{ Specification } & \multicolumn{3}{|l|}{ Norway } & \multicolumn{2}{|l|}{ Denmark } & \multicolumn{2}{|l|}{ Finland } & \multicolumn{2}{|l|}{ Sweden } \\
\hline & N1 & $\mathrm{N} 2$ & N3 & D1 & D2 & $\mathrm{F} 1$ & F2 & S1 & $\mathrm{S} 2$ \\
\hline \multicolumn{10}{|l|}{$\mathrm{BOD}\left(\mathrm{mg} \mathrm{Ol}^{-1}\right)$} \\
\hline Inlet $^{*}$ & $\begin{array}{l}360.0(95.4) \\
n=4\end{array}$ & $\begin{array}{l}174.0 \\
n=20\end{array}$ & $\begin{array}{l}174.0 \\
n=20\end{array}$ & $\begin{array}{l}316.0(55.4) \\
n=10\end{array}$ & $\begin{array}{l}405.0(91.5) \\
n=4\end{array}$ & $\begin{array}{l}211.9 \\
(135.3) \\
n=12\end{array}$ & $\begin{array}{l}203.1 \\
n=10\end{array}$ & $\begin{array}{l}55.5(32.4) \\
n=12\end{array}$ & $\begin{array}{l}234.7(74.8) \\
n=15\end{array}$ \\
\hline Pre-filter effluent & $\begin{array}{l}73.2(60.2) \\
n=10\end{array}$ & $\begin{array}{l}7.9(5.4) \\
n=20\end{array}$ & $\begin{array}{l}22.9(20.9) \\
n=7\end{array}$ & $\begin{array}{l}48.0(57) \\
n=10\end{array}$ & $\begin{array}{l}65.0(63.6) \\
n=2\end{array}$ & $\begin{array}{l}21.3(8.4) \\
n=10\end{array}$ & $\begin{array}{l}10.7(9) \\
n=10\end{array}$ & $\begin{array}{l}18.3(18.2) \\
n=30\end{array}$ & $\begin{array}{l}37.2(36.2) \\
n=17\end{array}$ \\
\hline Filter bed effluent & $\begin{array}{l}69.2(13.7) \\
n=11\end{array}$ & $\begin{array}{l}5.4(6.3) \\
n=20\end{array}$ & $\begin{array}{l}7.1(6.2) \\
n=15\end{array}$ & $\begin{array}{l}3.3(2.9) \\
n=10\end{array}$ & $\begin{array}{l}1.3(0.6) \\
n=3\end{array}$ & $\begin{array}{l}19.1(34) \\
n=14\end{array}$ & $\begin{array}{l}7.0(8.3) \\
n=10\end{array}$ & $\begin{array}{l}11.4(6.7) \\
n=11\end{array}$ & $\begin{array}{l}32.7(20.6) \\
n=15\end{array}$ \\
\hline$\%$ removal & 80.8 & 96.9 & 95.9 & 99.0 & 99.7 & 91.0 & 96.5 & 80.0 & 86.1 \\
\hline \multicolumn{10}{|l|}{$\mathrm{TP}\left(\mathrm{mg} \mathrm{l}^{-1}\right)$} \\
\hline Inlet $^{*}$ & $\begin{array}{l}13.3(1.5) \\
n=11\end{array}$ & $\begin{array}{l}6.6(2.5) \\
n=25\end{array}$ & $\begin{array}{l}6.6(2.5) \\
n=25\end{array}$ & $\begin{array}{l}26.8(9.2) \\
n=10\end{array}$ & $\begin{array}{l}21.2(5.4) \\
n=5\end{array}$ & $\begin{array}{l}18.2(7.6) \\
n=18\end{array}$ & $\begin{array}{l}11.7(1.8) \\
n=14\end{array}$ & $\begin{array}{l}8.0(5.3) \\
n=63\end{array}$ & $\begin{array}{l}9.5(2.7) \\
n=74\end{array}$ \\
\hline Pre-filter effluent & $\begin{array}{l}7.07(3.73) \\
n=6\end{array}$ & $\begin{array}{l}4.6(1.7) \\
n=25\end{array}$ & $\begin{array}{l}5.5(2.1) \\
n=9\end{array}$ & $\begin{array}{l}24.0(8.8) \\
n=10\end{array}$ & $\begin{array}{l}2.5(0.9) \\
n=5\end{array}$ & $\begin{array}{l}14.0(6.7) \\
n=16\end{array}$ & $\begin{array}{l}10.6(2.4) \\
n=14\end{array}$ & $\begin{array}{l}6.9(4.9) \\
n=63\end{array}$ & $\begin{array}{l}7.8(2.8) \\
n=73\end{array}$ \\
\hline Filter bed effluent & $\begin{array}{l}0.22(0.02) \\
n=11\end{array}$ & $\begin{array}{l}0.18(0.5) \\
n=28\end{array}$ & $\begin{array}{l}0.04(0.03) \\
n=20\end{array}$ & $\begin{array}{l}1.22(1.32) \\
n=10\end{array}$ & $\begin{array}{l}0.09(0) \\
n=5\end{array}$ & $\begin{array}{l}0.02(0.01) \\
n=20\end{array}$ & $\begin{array}{l}0.64(0.79) \\
n=14\end{array}$ & $\begin{array}{l}0.02(0.03) \\
n=107\end{array}$ & $\begin{array}{l}0.05(0.07) \\
n=48\end{array}$ \\
\hline$\%$ removal & 98.3 & 97.3 & 99.4 & 95.4 & 99.6 & 99.9 & 94.5 & 99.7 & 99.5 \\
\hline \multicolumn{10}{|l|}{$\mathrm{TN}\left(\mathrm{mg} \mathrm{l}^{-1}\right)$} \\
\hline Inlet $^{*}$ & $\begin{array}{l}132.1(26.2) \\
n=11\end{array}$ & $\begin{array}{l}67.4(22.7) \\
n=20\end{array}$ & $\begin{array}{l}67.4(22.7) \\
n=20\end{array}$ & $\begin{array}{l}90.0(9.7) \\
n=10\end{array}$ & $\begin{array}{l}93.6(24.5) \\
n=5\end{array}$ & $\begin{array}{l}92.3(60.1) \\
n=18\end{array}$ & $\begin{array}{l}45.0(12.8) \\
n=14\end{array}$ & $\begin{array}{l}47.6(29.6) \\
n=50\end{array}$ & $\begin{array}{l}55.8(15.2) \\
n=57\end{array}$ \\
\hline Pre-filter effluent & $\begin{array}{l}106.8(39.2) \\
n=11\end{array}$ & $\begin{array}{l}52.4(27.6) \\
n=24\end{array}$ & $\begin{array}{l}56.1(17.9) \\
n=8\end{array}$ & $\begin{array}{l}49.0(11.6) \\
n=10\end{array}$ & $\begin{array}{l}66.1(12.2) \\
n=5\end{array}$ & $\begin{array}{l}65.3(12.5) \\
n=16\end{array}$ & $\begin{array}{l}33.3(10.5) \\
n=14\end{array}$ & $\begin{array}{l}45.5(24.5) \\
n=51\end{array}$ & $\begin{array}{l}40.0(13.8) \\
n=58\end{array}$ \\
\hline Filter bed effluent & $\begin{array}{l}81.7(21.7) \\
n=11\end{array}$ & $\begin{array}{l}45.8(20.3) \\
n=20\end{array}$ & $\begin{array}{l}28.0(14.6) \\
n=14\end{array}$ & $\begin{array}{l}33.9(9.2) \\
n=10\end{array}$ & $\begin{array}{l}48.3(6.9) \\
n=5\end{array}$ & $\begin{array}{l}61.2(32.9) \\
n=20\end{array}$ & $\begin{array}{l}29.7(4.6) \\
n=14\end{array}$ & $\begin{array}{l}22.6(11.4) \\
n=98\end{array}$ & $\begin{array}{l}19.0(10.1) \\
n=48\end{array}$ \\
\hline$\%$ removal & 38.1 & 32.1 & 58.5 & 62.3 & 48.4 & 33.7 & 33.9 & 52.6 & 65.9 \\
\hline \multicolumn{10}{|l|}{$\mathrm{NH}_{4}^{+}\left(\mathrm{mg} \mathrm{l}^{-1}\right)$} \\
\hline Inlet $^{*}$ & $\begin{array}{l}132.0(12) \\
n=11\end{array}$ & $\begin{array}{l}67.3(17.6) \\
n=20\end{array}$ & $\begin{array}{l}67.3(17.6) \\
n=20\end{array}$ & $\begin{array}{l}89.7(10.6) \\
n=10\end{array}$ & $\begin{array}{l}93.4(18.9) \\
n=5\end{array}$ & $\begin{array}{l}91.3(41.9) \\
n=18\end{array}$ & $\begin{array}{l}44.0(11.7) \\
n=14\end{array}$ & $\begin{array}{l}47.1(27.8) \\
n=50\end{array}$ & $\begin{array}{l}55.3(13.9) \\
n=57\end{array}$ \\
\hline Pre-filter effluent & $\begin{array}{l}102.9(32) \\
n=10\end{array}$ & $\begin{array}{l}12.0(17.3) \\
n=24\end{array}$ & $\begin{array}{l}22.5(21.2) \\
n=8\end{array}$ & $\begin{array}{l}21.5(15) \\
n=10\end{array}$ & $\begin{array}{l}56.2(29.5) \\
n=5\end{array}$ & $\begin{array}{l}13.6(11.2) \\
n=16\end{array}$ & $\begin{array}{l}10.4(8.2) \\
n=14\end{array}$ & $\begin{array}{l}16.5(15.2) \\
n=50\end{array}$ & $\begin{array}{l}20.2(16.9) \\
n=57\end{array}$ \\
\hline Filter bed effluent & $\begin{array}{l}81.0(22.7) \\
n=11\end{array}$ & $\begin{array}{l}13.4(17.2) \\
n=20\end{array}$ & $\begin{array}{l}14.5(14.2) \\
n=12\end{array}$ & $\begin{array}{l}19.2(11.8) \\
n=10\end{array}$ & $\begin{array}{l}26.5(19.2) \\
n=5\end{array}$ & $\begin{array}{l}23.2(41) \\
n=20\end{array}$ & $\begin{array}{l}13.9(7.4) \\
n=14\end{array}$ & $\begin{array}{l}16.2(11.4) \\
n=96\end{array}$ & $\begin{array}{l}15.9(10.4) \\
n=48\end{array}$ \\
\hline$\%$ removal & 38.6 & 80.1 & 78.5 & 78.6 & 71.7 & 74.5 & 68.5 & 65.6 & 71.2 \\
\hline \multicolumn{10}{|l|}{$\mathrm{NO}_{3}^{-}, \mathrm{NO}_{2}{ }^{-}\left(\mathrm{mg} \mathrm{l}^{-1}\right)$} \\
\hline Inlet $^{*}$ & $\begin{array}{l}0.1(0.1) \\
n=4\end{array}$ & $\begin{array}{l}0.1(0.3) \\
n=15\end{array}$ & $\begin{array}{l}0.1(0.3) \\
n=15\end{array}$ & $\begin{array}{l}0.3(0.5) \\
n=10\end{array}$ & $\begin{array}{l}0.1(0) \\
n=5\end{array}$ & $\begin{array}{l}1.1(0.2) \\
n=6\end{array}$ & $\begin{array}{l}1.0(0) \\
n=3\end{array}$ & $\begin{array}{l}0.5(0) \\
n=22\end{array}$ & $\begin{array}{l}0.5(0) \\
n=22\end{array}$ \\
\hline Pre-filter effluent & $\begin{array}{l}3.9(8.5) \\
n=11\end{array}$ & $\begin{array}{l}40.4(21.2) \\
n=22\end{array}$ & $\begin{array}{l}33.6(28.7) \\
n=8\end{array}$ & $\begin{array}{l}27.6(13.1) \\
n=10\end{array}$ & $\begin{array}{l}9.9(9.1) \\
n=5\end{array}$ & $\begin{array}{l}51.7(12.3) \\
n=15\end{array}$ & $\begin{array}{l}22.9(9.7) \\
n=14\end{array}$ & $\begin{array}{l}29.0(12.3) \\
n=51\end{array}$ & $\begin{array}{l}19.8(16.6) \\
n=58\end{array}$ \\
\hline Filter bed effluent & $\begin{array}{l}0.7(0.7) \\
n=10\end{array}$ & $\begin{array}{l}32.4(22) \\
n=19\end{array}$ & $\begin{array}{l}13.5(9.2) \\
n=14\end{array}$ & $\begin{array}{l}14.7(10.5) \\
n=10\end{array}$ & $\begin{array}{l}21.8(9.3) \\
n=5\end{array}$ & $\begin{array}{l}38.0(18.8) \\
n=19\end{array}$ & $\begin{array}{l}15.9(6.7) \\
n=14\end{array}$ & $\begin{array}{l}6.4(5.4) \\
n=98\end{array}$ & $\begin{array}{l}3.1(1.8) \\
n=48\end{array}$ \\
\hline \multicolumn{10}{|l|}{$\mathrm{TSS}\left(\mathrm{mg} \mathrm{l}^{-1}\right)$} \\
\hline Inlet $^{*}$ & $\begin{array}{l}105(40.6) \\
n=7\end{array}$ & $\begin{array}{l}76(17.4) \\
n=22\end{array}$ & $\begin{array}{l}76(17.4) \\
n=22\end{array}$ & $\begin{array}{l}97,5(26.6) \\
n=9\end{array}$ & $\begin{array}{l}88.4(20.9) \\
n=5\end{array}$ & $\begin{array}{l}93.7(68.4) \\
n=18\end{array}$ & $\begin{array}{l}55.3(16) \\
n=14\end{array}$ & $\begin{array}{l}42.3(17.7) \\
n=20\end{array}$ & $\begin{array}{l}97.5(31) \\
n=27\end{array}$ \\
\hline Pre-filter effluent & $\begin{array}{l}24(22.7) \\
n=6\end{array}$ & $\begin{array}{l}11.0(20.5) \\
n=24\end{array}$ & $\begin{array}{l}9(6) \\
n=12\end{array}$ & $\begin{array}{l}18.3(17.2) \\
n=9\end{array}$ & $\begin{array}{l}66.8(34.9) \\
n=5\end{array}$ & $\begin{array}{l}48.6(36.4) \\
n=16\end{array}$ & $\begin{array}{l}26.6(58.3) \\
n=14\end{array}$ & $\begin{array}{l}10.2(13.1) \\
n=20\end{array}$ & $\begin{array}{l}48,9(49.6) \\
n=25\end{array}$ \\
\hline Filter bed effluent & $\begin{array}{l}5(0) \\
n=4\end{array}$ & $\begin{array}{l}19.9(22.1) \\
n=17\end{array}$ & $\begin{array}{l}20.0(14.9) \\
n=6\end{array}$ & $\begin{array}{l}6.4(3.6) \\
n=9\end{array}$ & $\begin{array}{l}5.1(2.8) \\
n=5\end{array}$ & $\begin{array}{l}6.6(4) \\
n=20\end{array}$ & $\begin{array}{l}9.9(15.8) \\
n=14\end{array}$ & $\begin{array}{l}6.4(5.3) \\
n=63\end{array}$ & $\begin{array}{l}16.5(14.2) \\
n=30\end{array}$ \\
\hline$\%$ removal & 95.0 & 73.8 & 73.7 & 94.3 & 94.2 & 93.0 & 82.1 & 84.9 & 70.3 \\
\hline Fecal indicator bacter & $\mathrm{a} / 100 \mathrm{ml}$ & & & & & & & & \\
\hline Bacteria type & a & $\mathrm{b}$ & - & $\mathrm{a}$ & $\mathrm{a}$ & c & $\mathrm{c}$ & $\mathrm{b}$ & b \\
\hline Filter bed effluent & 0 & 0 & - & $<3$ & 0 & $<10$ & $<300$ & 0 & 0 \\
\hline
\end{tabular}

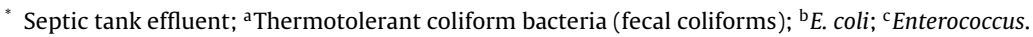

An important part of the investigations was to study the performance of different treatment steps in the systems. The first step takes place in the septic tank, which represents an anaerobic treatment method, the oldest and the most common for onsite domestic wastewater treatment (Ntengwe, 2005; Seghezzo et al., 1998). The removal in the septic tank was not considered in this study and septic tank effluent served as the baseline inflow data in the analysis below. The relative contribution to the overall performance of the biofilter unit and the saturated filter is displayed in Fig. 4.

\subsection{Removal of organic matter (BOD)}

The major reduction of BOD occurred in the aerobic vertical flow biofilter (Fig. 4). In five systems the biofilter effluent was below $25 \mathrm{mg} / \mathrm{l}$. The best performing filter was N2 where the pump was operated on a timer giving 48 doses per day. All other filters were operated on float switches and had a less frequent dosing regime. The lowest removal efficiency of organic matter was observed in the N1 system. That was probably due to higher BOD loading in comparison to the other systems (Table 2), and larger grain size of 




Fig. 3. Effluent concentrations vs. time of organic matter (TOC) and total phosphorus (P) in system S2.

\section{(a) BOD}



(b) TP



(c) $\mathbf{T N}$

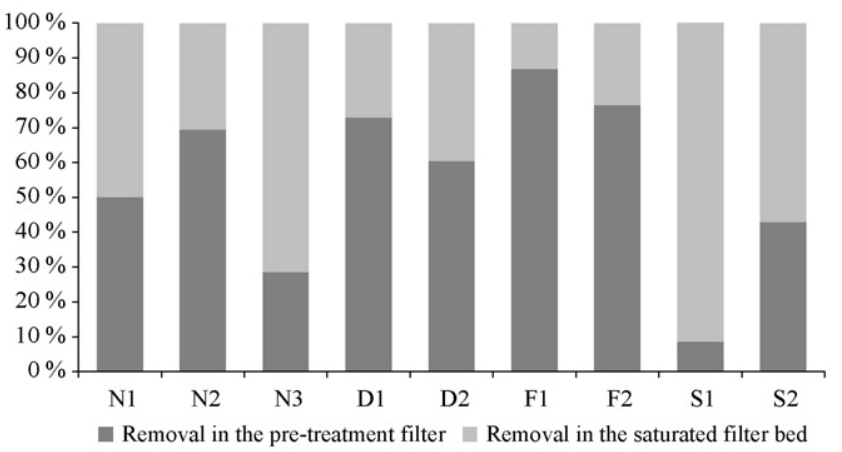

Fig. 4. The relative contribution to the overall removal of: (a) BOD, (b) TP and (c) $\mathrm{TN}$ in the pre-treatment filter and the horizontal saturated filter bed of the tested systems. media used in the biofilter (Table 1 ) resulting in substantially less biofilm area. The BOD also increased through the filterbed. This may be attributed to organic matter leaching from the grass layer above the filter before the grass layer had stabilized and a good cover was grown.

Systems D1 and D2 practiced recycling of the effluent from the filter bed to the septic tank, which caused a higher hydraulic load on the biofilter, something which may have reduced the BOD removal performance of these two biofilters. The systems with biofilters covered by domes generally performed better than systems with biofilters in tanks except for in system F2. The better air access in the dome systems compared to the tanks may explain this difference. The filter bed further polishes the effluent and five systems produced BOD values below $10 \mathrm{mg} / \mathrm{l}$. In general, the BOD effluent values were lower towards the end of the testing period and several samples were below $5 \mathrm{ppm}$ the lower detection limit of the BOD analysis. It is expected that the long-term BOD performance will be better than the values presented herein.

\subsection{Phosphorus removal}

The biofilters removed substantial amounts of TP during the initial 6-12 months of operation, but then became saturated and the majority of the long-term P removal occurred in the subsurface horizontal flow filter beds (Fig. 4). This phenomenon was attributed to the high P-sorption capacity of LWA, Filtralite ${ }^{\circledR} \mathrm{P}$, used in the filter beds. The high removal observed in the biofilter system of D2 (Table 2 and Fig. 4) was not an exception from this phenomenon, but a consequence of siphoned backflow of $\mathrm{Ca}$-rich water from the filter bed to the biofilter where precipitation of P occurred.

The high removal efficiency resulted in low TP concentration $\left(<1.0 \mathrm{mg} \mathrm{Pl}^{-1}\right)$ in the final effluents from almost all systems (Table 2). An exception was found in effluents from, the D1 system that had the highest initial $\mathrm{P}$ loading. To maintain the high treatment efficiency for phosphorus, the filter material in the saturated filter bed has to be exchanged when P concentration in the effluent exceeds the discharge limit, e.g. $1.0 \mathrm{mg} \mathrm{Pl}^{-1}$ for small systems in many Norwegian municipalities (Johannessen et al., 2008). An estimated lifetime of filter media is 15 years for a $40 \mathrm{~m}^{3}$ bed when the inlet values are about $10 \mathrm{mg} \mathrm{Pl}^{-1}$ (Jenssen and Krogstad, 2002). The compact (N2, N3, F2, S1) filter beds produced as low effluent values as the large $(\mathrm{N} 1, \mathrm{D} 1, \mathrm{D} 2, \mathrm{~F} 1, \mathrm{~S} 2)$ beds indicating that the 
maximum P-sorption capacity was not reached even in the most compact systems (N2 and F1). However, more frequent exchange of the filter media will be needed in the compact systems. In systems $\mathrm{N} 2$ and F2, the filter beds were confined in tanks that facilitates the renewal of the media.

\subsection{Nitrogen removal and transformations}

The removal of TN in the systems varied from 32 to $66 \%$ (Table 2). More than half of the examined systems revealed high TN removal in the pre-treatment biofilters (Fig. 4). In system N2, the total TN removal was the lowest (32\%) but $70 \%$ of this occurred in the biofilter. Such high removal under predominantly aerobic conditions was quite surprising especially when this filter also had high BOD reduction. However, up to $40 \%$ of TN removal was observed in a column experiment simulating the conditions of such pre-treatment biofilters (Kraft, 2002). It might be speculated that denitrification happen in the deeper, anoxic layers of the biofilm or other anoxic microsites in the filter (Lance, 1972). Denitrification could also take place in anaerobic sites of the LWA particles. However, diffusion in and out of the LWA particles at a rate sufficient to account for significant denitrification is unlikely.

The ammonia $\left(\mathrm{NH}_{4}\right)$ removal ranged from 38 to $80 \%$ and the majority happened, as expected, in the aerobic biofilter. The $\mathrm{NH}_{4}$ removal in the subsequent filter beds is generally low although some ammonia volatilization can be expected due to the high initial $\mathrm{pH}$ of 12-13. This can probably account for the relatively large $\mathrm{NH}_{4}$ removal in the filter bed of system $\mathrm{N} 1$ where the nitrification as well as the BOD reduction in the biofilter was low.

The total N-removal was in the same range as the $\mathrm{N}$-removal in systems with biofilters and subsurface flow CW's as the final treatment step (Jenssen et al., 2005) despite that a lower removal could be expected due to the lack of plants (Zhu, 1998). The more advanced biofilters in this investigation having improved distribution systems (Heistad et al., 2001) that gives better distribution of the biofilm and a larger biofilm area as compared to the investigation of Jenssen et al. (2005) may explain this.

\subsection{Total suspended solids (TSS) removal}

The effluent from all systems was clear indicating a high TSS removal and all systems except N2, N3 and S2 produced an effluent below $10 \mathrm{mg} / \mathrm{l}$. In N2, and N3 the TSS values increased through the filter bed. This is due to the high calcium (Ca) content of the Filtralite ${ }^{\circledR} \mathrm{P}$ resulting in dissolved $\mathrm{Ca}$ in the effluent. Initially the Filtralite ${ }^{\circledR} \mathrm{P}$ bleeds $\mathrm{Ca}$, but this normally ceases with time as shown in batch and column experiments (Adam et al., 2007).

\subsection{Bacteria and virus removal}

The criteria for excellent inland bathing water quality require $<500$ E. coli $/ 100 \mathrm{ml}$ or $<200$ Enterococci/ $100 \mathrm{ml}$ (CEC, 2006). Table 2 displays the maximum bacteria concentrations in the effluent. Only one sample exceeded the above criteria (F2). On the average all systems produced excellent bathing water quality with respect to indicator bacteria. In addition, tests with somatic coliphages were performed in the Norwegian compact filter system (N2). No viruses were detected in the effluent (Heistad et al., 2006). This result could be explained by an inactivation effect due to the high initial $\mathrm{pH}$ of the LWA ( $\mathrm{pH}$ of 12-13). After three years of operation, the $\mathrm{pH}$ of the filter media decreased to $9-10$. This is still far above the point of zero charge, keeping the viruses negatively charged, hence, very mobile in most soil media. High $\mathrm{P}$ removal capacity is often associated with high removal of bacteria and viruses (Schijven and Hassanizadeh, 2000). Patches of positively charged iron- and aluminium oxides in the LWA-Filtralite ${ }^{\circledR} \mathrm{P}$ are assumed to attract negatively charged virus particles, also after a decrease in pH levels (Heistad et al., 2006). High concentration of calcium- and magnesium-ions in the LWA-Filtralite ${ }^{\circledR} \mathrm{P}$ may also facilitate salt bridge effects between negatively charged surfaces. Jenssen et al. (2005) reported that removal of indicator bacteria in old CWs using similar LWA, but with $\mathrm{pH}$ level nearly neutral, was still very efficient resulting in effluent TCB concentrations below 100 colony forming units per $100 \mathrm{ml}$

\subsection{Recycling of used filter media}

Results of chemical analyses of Filtralite ${ }^{\circledR} \mathrm{P}$ (Tables 3 and 4 ) showed that the material had accumulated only a small amount of P during the initial period of operation (one to two years of domestic wastewater treatment), lactate extractable P corresponding to a soil of "low medium" P status (Krogstad et al., 2008). Most of the P was obviously structural, being inherent from the subsoil clay used as the raw material of Filtralite ${ }^{\circledR} \mathrm{P}$. The first pot experiment (results not shown) also revealed that ryegrass was able to take up only $3 \%$ of P applied in the used filter material, confirming that this material could not yet be considered as a $P$ fertilizer.

Filtralite ${ }^{\circledR}$ P possess a large capacity to retain P. The material saturated with $\mathrm{P}$ in the laboratory had adsorbed about $7500 \mathrm{mg} \mathrm{P} \mathrm{kg}^{-1}$, as compared to the pristine filter material (Table 3). Most of it was extractable with ammonium lactate ( $\mathrm{pH} 3.75$ ) but only a small proportion of it was dissolved with water. This outcome is in line with the results of the Chang and Jackson fractionation, where majority of retained $\mathrm{P}$ in the saturated filter material was recovered by $\mathrm{H}_{2} \mathrm{SO}_{4}$ extraction. Typically, $\mathrm{P}$ bound at high $\mathrm{pH}$ by materials rich in $\mathrm{Ca}$, such as Filtralite ${ }^{\circledR} \mathrm{P}$, is in the form of Ca phosphates, which are easily soluble in acids. As observed earlier (Zhu et al., 2003), the concentration of $\mathrm{NaOH}$ extractable $\mathrm{P}$, representing Fe bound forms, was negligible in the Filtralite ${ }^{\circledR} \mathrm{P}$ materials, as compared to soil. It is likely that during manufacturing of the material at high temperature $\left(1200^{\circ} \mathrm{C}\right.$, Zhu et al., 2003) the crystallinity of Fe minerals is increased, decreasing their P-sorption capacity.

The results of the pot experiment (Table 5) showed that ryegrass was able to utilize $\mathrm{P}$ accumulated in the material. As measured by crop uptake in the three yields, the utilization of $\mathrm{P}$ added as Filtralite ${ }^{\circledR} \mathrm{P}$ and as $\mathrm{Ca}\left(\mathrm{H}_{2} \mathrm{PO}_{4}\right)_{2}$ was on average 24 and $37 \%$, respectively. The difference between the two fertilizers was due to greater $\mathrm{P}$ uptake from $\mathrm{Ca}\left(\mathrm{H}_{2} \mathrm{PO}_{4}\right)_{2}$ in the first yield while there was no difference in the amounts of $\mathrm{P}$ supplied from $\mathrm{Ca}\left(\mathrm{H}_{2} \mathrm{PO}_{4}\right)_{2}$ and saturated Filtralite ${ }^{\circledR} \mathrm{P}$ in the last two yields. The supply of $\mathrm{P}$ from the fertilizers was not yet exhausted by the three yields. Even in the last yield the $\mathrm{P}$ concentration in the plant material was $1.7-2.3 \mathrm{mg} \mathrm{g}^{-1}$ and $1.7-1.9 \mathrm{mg} \mathrm{g}^{-1}$ at the various levels of $\mathrm{Ca}\left(\mathrm{H}_{2} \mathrm{PO}_{4}\right)_{2}$ and Filtralite ${ }^{\circledR} \mathrm{P}$, respectively, as compared to $1.5 \mathrm{mg} \mathrm{g}^{-1}$ in the grass not fertilized with $\mathrm{P}$. The efficiency of Filtralite ${ }^{\circledR} \mathrm{P}$ was calculated as $65 \%$ of the efficiency of $\mathrm{Ca}\left(\mathrm{H}_{2} \mathrm{PO}_{4}\right)_{2}$. Unused pristine Filtralite ${ }^{\circledR} \mathrm{P}$ had no P fertilizer value.

The filter media had a liming value of $4.5 \mathrm{~mol} \mathrm{~kg}^{-1}$, corresponding to about $22 \%$ of that in pure calcium carbonate. An important note from the experiments was drawn that the reused filter media did not show any adverse effects on plant growth.

The above results show that the P-rich filter media can be reused as a plant fertilizer, a soil amendment or a conditioner, provided the material meet requirements regarding hygiene and heavy metals. In Norway, the maximum permissible concentrations of $\mathrm{Cd}$ is 2 ppm, $\mathrm{Pb}-80$ ppm, $\mathrm{Hg}-3 \mathrm{ppm}, \mathrm{Ni}-50 \mathrm{ppm}, \mathrm{Zn}-800 \mathrm{ppm}, \mathrm{Cu}-$ $650 \mathrm{ppm}$ and $\mathrm{Cr}-100 \mathrm{ppm}$ (FOR, 2003). The Norwegian regulation (FOR, 2003) defines the highest number of TCB to $2.50 \mathrm{E}+03 \mathrm{cfu} / \mathrm{g}$ 
Table 3

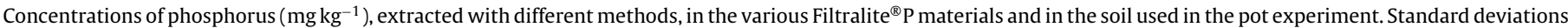
are expressed in the parentheses.

\begin{tabular}{|c|c|c|c|c|}
\hline \multirow[t]{2}{*}{ Sample } & \multirow[t]{2}{*}{ Total } & \multicolumn{3}{|c|}{ Extraction method } \\
\hline & & $\mathrm{AR}^{\mathrm{a}}$ & $\mathrm{AL}^{\mathrm{b}}$ & Water \\
\hline Unused filter & $1480(34)$ & $870(45)$ & n.d. & $0.15(-)^{c}$ \\
\hline Used filter (exp. 1) & $1700(7.1)$ & $1060(17)$ & $47(0.8)$ & $0.2(0.2)$ \\
\hline Saturated filter (exp. 2) & 9030 (117) & $6950(85)$ & $4650(-)^{c}$ & $69(-)^{c}$ \\
\hline Soil (pot exp.) & $640(6)$ & n.d. & $10(0.4)$ & $1.70 .5)$ \\
\hline
\end{tabular}

a Aqua regia extraction.

b Ammonium lactate extraction.

c No replicates, n.d. $=$ not determined.

Table 4

Fractions of inorganic $\mathrm{P}\left(\mathrm{mg} \mathrm{kg}^{-1}\right)$ in the filter materials and in the soil used in the pot experiment. Standard deviations are expressed in the parentheses.

\begin{tabular}{|c|c|c|c|c|}
\hline \multirow[t]{2}{*}{ Sample } & \multirow[t]{2}{*}{$\mathrm{NH}_{4} \mathrm{Cl}$} & \multicolumn{3}{|c|}{ P extracted with } \\
\hline & & $\mathrm{NH}_{4} \mathrm{~F}$ & $\mathrm{NaOH}$ & $\mathrm{H}_{2} \mathrm{SO}_{4}$ \\
\hline Unused filter & $8(0.0)$ & $37(0.8)$ & $<1(0.1)$ & $860(7.6)$ \\
\hline Used filter (exp. 1) & $10(0.4)$ & $68(0.8)$ & $2(0.0)$ & $1082(3.0)$ \\
\hline Saturated filter (exp. 2) & $53(0.0)$ & $1641(15.0)$ & $22(2.3)$ & $4811(35.1)$ \\
\hline Soil (pot exp.) & $0.3(0.2)$ & $42(0.8)$ & $107(0.9)$ & $132(0.8)$ \\
\hline
\end{tabular}

TS, and in addition Salmonella bacteria and/or infective parasite eggs should be absent.

Theoretically, the LWA materials have a low sorption capacity for heavy metals. This has been confirmed by the tests of media samples (Paruch et al., 2007) showing that the accumulation did not exceed the maximum permissible contents of heavy metals in materials applied to agriculture (FOR, 2003).

The numbers of faecal indicator bacteria in tested materials varied between $2.90 \mathrm{E}+00$ and $1.10 \mathrm{E}+03 \mathrm{TCB} / \mathrm{g}$ TS (Paruch et al., 2007) and thus did not exceed the upper limit of TCB in materials applied on cultivated areas in Norway. The tested filter media did not reveal any contamination with the examined viruses. In addition, neither Salmonella bacteria nor parasite eggs were detected (Paruch et al., 2007). The investigated systems treated domestic wastewater from approx. 100 persons and therefore might not be representative of the emissions of heavy metals and pathogens from the population in general. However, the obtained results indicate that recycling of the used filter materials in agriculture should be within acceptable risk.

\section{Practical remarks}

One important difference between the small-scale (package) conventional systems for phosphorus removal and the subsurface flow constructed wetlands (CWs), is that the chemicals (the coagulants) in the conventional systems are dosed continuously from containers using pumps etc. Sufficient chemicals must be available at all times, and the correct dose of coagulant in relation to flow, water quality, and $\mathrm{pH}$ must be present to maintain a consistent high phosphorus removal. For the filter beds and constructed wet- land systems the phosphorus-sorbing chemicals are a part of the porous media filter system and will continue to perform until the absorption capacity is exhausted. This happens as a slow increase in effluent values (Fig. 3) and thus a predictable and stable highperformance is achieved. This is in contrast to package treatment systems that has unstable performance and problems of reaching and average effluent concentration of $1 \mathrm{mg} / \mathrm{l}$ which is required in many parts of Norway (Johannessen et al., 2008).

All the tested systems except N2 and F2 had investment costs of approx. 16000 USD per household. This equals or exceeds other onsite options as septic tank soil absorption systems or package treatment systems. The operation and maintenance costs (O\&M) of the filter bed systems are low as for natural systems in general (Refsgaard and Etnier, 1998) thus, the yearly cost (O\&M + capital cost) competes well with more package systems. The main operational costs are electricity to run the pump, pumping of the septic tank at given intervals and a recommended annual inspection of the pump and biofilter. The high investment cost is due to the size of the filter bed $\left(40 \mathrm{~m}^{2}\right)$ and the relatively high cost of the Filtralite ${ }^{\circledR} \mathrm{P}$ (approx $30 \%$ of total cost). However, this investigation has shown that it is possible to build the filter bed much smaller $\left(<10 \mathrm{~m}^{3}\right)$ without sacrificing treatment performance. This can significantly reduce the investment cost, but will increase operational costs as the Filtralite ${ }^{\circledR} \mathrm{P}$ will have to be changed more frequently. The smaller size will facilitate building of this type systems on small lots or under difficult ground conditions. The smaller filter beds $\left(<10 \mathrm{~m}^{3}\right)$ can be confined i.e. in a fibreglas tank. This can further reduce investment costs as construction takes less time. Thus the compact filter beds should provide an option that competes well to package treatment plants in terms of investment cost, and in

Table 5

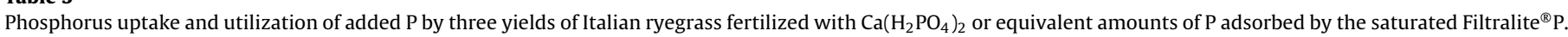
Standard deviation for P uptake is expressed in the parentheses.

\begin{tabular}{|c|c|c|c|c|}
\hline \multirow[t]{2}{*}{ P application ( $\mathrm{mg} \mathrm{kg}^{-1}$ ) } & \multicolumn{2}{|c|}{ P uptake ( $\mathrm{mg} \mathrm{kg}^{-1}$ of soil) } & \multicolumn{2}{|c|}{ Apparent utilization (\%) of $\mathrm{P}$} \\
\hline & $\mathrm{Ca}\left(\mathrm{H}_{2} \mathrm{PO}_{4}\right)_{2}$ & Filtralite ${ }^{\circledR} \mathrm{P}$ & $\mathrm{Ca}\left(\mathrm{H}_{2} \mathrm{PO}_{4}\right)_{2}$ & Filtralite ${ }^{\circledR} \mathrm{P}$ \\
\hline No $\mathrm{P}$ added & $12.3(0.6)$ & & & \\
\hline 20 & $20.4(0.6)$ & $19.1(0.9)$ & 41 & 34 \\
\hline 40 & $27.9(0.9)$ & $22.0(0.9)$ & 39 & 24 \\
\hline 60 & $33.6(0.9)$ & $27.5(2.4)$ & 36 & 25 \\
\hline 80 & $39.3(1.8)$ & $29.0(1.8)$ & 34 & 21 \\
\hline 100 & $45.5(2.5)$ & $30.3(0.6)$ & 33 & 18 \\
\hline
\end{tabular}


addition they have a high and more stable treatment performance. A fibreglas tank will also reduce the risk of leaks i.e. to underlying groundwater as compared to a larger plastic or bentonite lined filter bed.

The filter beds produce an effluent with an initial $\mathrm{pH}$ up to 13 . This is not a practical problem, because the volume flow is small and readily diluted even in very small streams. In Scandinavia many streams have a low $\mathrm{pH}$ and an input of extra alkalinity should be positive. The high $\mathrm{pH}$ effluent from test system N2 was successfully infiltrated in a clay soil for one year. The high pH will quickly be neutralized in most soils and should have a positive effect on the structure of aggregated soils.

Macrophytes normally supply oxygen to the wetland filter (Brix, 1990). In the grass-covered filter bed oxygen supply from the plants is not possible and thus the redox potential in the filterbed may be lower than in a bed covered with macropytes. The redox potential was not measured, but iron precipitates formed when the effluent was exposed to air. This indicates reducing conditions in the filterbed.

\section{Conclusions}

1. The filter bed systems showed stable and consistent highperformance during the testing period. The main removal of organic matter and substantial reduction of nitrogen occurred in the pre-treatment biofilter, while the removal of pathogens to reach bathing water quality with respect to indicator bacteria took place in the saturated filter.

2. The treatment capacity of the filter beds does not differ significantly from the similar biofilter/constructed wetland systems tested earlier, indicating that substituting the wetland plants for grass does not reduce the overall treatment capacity.

3. The study revealed that systems with small saturated filters performed as well as the systems with large filters. Therefore, the saturated filter can be built smaller without sacrificing the overall treatment performance. However, the smaller filters will reach P-saturation quicker and thus, need more frequent exchange of the filter material. The compact filter beds can provide a solution for sites where the available area is limited.

4. The filter bed wastewater treatment system shows a high and stable phosphorus removal and is a good alternative to compact package treatment plants that need a frequent supply of chemicals in order to remove phosphorus.

5. The investigated systems had low operation and maintenance demands. The main costs were related to pumping of the septic tank. The pump and pre-treatment biofilter should be checked annually.

6. The filter media that were used met the Norwegian regulations for reuse in agriculture with respect to heavy metals and pathogens; thus, the material can be safely recycled to agriculture.

7. Reuse of the phosphorus saturated light-weight aggregates of type Filtralite ${ }^{\circledR} \mathrm{P}$ has a positive fertilizer and liming effect.

\section{Acknowledgements}

The project (NI Project 02056 "Wastewater treatment in filter beds") and the studies have been funded by the Nordic Innovation Centre (NICe), and partially by the research programme "Recycling of organic waste-effects on soil quality, plant nutrition supply and environmental impact", which has been supported by the Research Council of Norway (Grant No. 173496/I30).

\section{References}

Adam, K., Krogstad, T. Vråle, L., Søvik, A.K. Jenssen, P.D., 2007. Phosphorus retention in the filter materials shellsand and Filtralite $\mathrm{P}$ - batch and column experiment with synthetic P solution and secondary wastewater. Ecol. Eng. 29, 200 208.

Allestam, G., Carlander, A., 2000. Bacteriophages as Tracers and Hygiene Indicator Laboratory Manual. Swedish Institute for Infection Disease Control, SE-171 82 Solna, Sweden.

APHA/AWWA/WPCF, 1989. Standard Methods for the Examination of Water and Wastewater, 17 th ed. Washington, DC, USA

Bowman, R., 1988. A rapid method to determine total phosphorus in soils. Soil Sci. Soc. Am. J. 52, 1301-1304.

Brix, H., 1990. Gas exchange through the soil-atmosphere interface and through dead culms of phragmites australis in a constructed reed bed receiving domestic sewage. Water Res. 24 (2), 259-266.

Brix, H., Arias, C.A., 2005. The use of vertical flow constructed wetlands for on-site treatment of domestic wastewater: the new Danish guidelines. Ecol. Eng. 25 (5) 491-500.

CEC, 2006. EU Directive 2006/7/EC of the European Parliament and of the Council of 15 February 2006 Concerning the Management of Bathing Water Quality and Repealing Directive 76/160/EEC. Official Journal of the European Union 4.3.2006, L 64/37, Brussels.

Decamp, O., Warren, A., Sanchez, R., 1999. The role of ciliated protozoa in subsurface flow wetlands and their potential as bioindicators. Water Sci. Technol. 40 (3), 91-98.

Egner, H., Riehm, H., Domingo, W.R., 1960. Untersuchungen über die chemische Bodenanalyse als Grundlage für die Beurteilung des Nährstoffzustandes de Böden. II. Chemische Extractionsmethoden zur Phosphor- und Kaliumbestimmung. Kungl. Högsk. Ann. 26, 199-215.

Føllesdal, M., 2005. NI Project 02056 Wastewater Treatment in Filter Beds. Common Report from all Pilot Plants. Maxit Group AB, Oslo, Norway.

FOR, 2003. Regulation on Fertiliser Products of Organic Origin. Department of Food and Agriculture, Department of the Environment, Department of Public Health (Forskrift om gjødselvarer mv. av organisk opphav. Landbruksdepartement, Miljøverndepartementet og Helsedepartementet 4. juli 2003). 2003-07-04 nr 951 , Oslo, Norway (in Norwegian).

Guppy, C.N., Menzies, N.W., Moody, P.W., Blamey, F.P.C., 2005. Competitive sorption reactions between phosphorus and organic matter in soil: a review. Australian J. Soil Res. 43, 189-202.

Hartikainen, H., 1979. Phosphorus and its reactions in terrestrial soils and lake sediments. J. Sci. Agric. Soc. Finl. 51, 537-624.

Heistad, A., Jenssen, P.D., Frydenlund, A.S., 2001. A new combined distribution and pretreatment unit for wastewater soil infiltration systems. In: Mancl, K. (Ed.) Onsite Wastewater Treatment. Proc. Ninth Int. Conf. on Individual and Small Community Sewage Systems. ASAE.

Heistad, A., Paruch, A.M., Vråle, L., Adam, K., Jenssen, P.D., 2006. A high-performance compact filter system treating domestic wastewater. Ecol. Eng. 28 (4), 374 379.

ISO, 1995a. Water Quality - Detection and Enumeration of Bacteriophages. Part 1: Enumeration of F-specific RNA Bacteriophages. ISO 10705-1, Geneva, Switzerland.

ISO, 1995b. Soil Quality - Extraction of Trace Elements Soluble in Aqua Regia. ISO 11466, Geneva, Switzerland.

ISO, 2000. Water Quality - Detection and Enumeration of Bacteriophages. Part 2 Enumeration of Somatic Coliphages. ISO 10705-2, Geneva, Switzerland.

Jenssen, P.D., Krogstad, T., 2002. Design of constructed wetlands using phosphorus sorbing lightweight aggregate (LWA). In: Mander, Ü., Jenssen, P.D. (Eds.), Constructed Wetlands for Wastewater Treatment in Cold Climates. Advances in Ecological Sciences, vol. 11. WIT Press, pp. 259-271.

Jenssen, P.D., Mæhlum, T., Krogstad, T., 1993. Potential use of constructed wetland for wastewater treatment in northern environments. Water Sci. Technol. 28 (10), 149-157.

Jenssen, P.D., Mæhlum, T., Krogstad, T., Vråle, L., 2005. High performance constructed wetlands for cold climates. J. Environ. Sci. Health Part A Toxic Hazard. Subst. Environ. Eng. 40 (6-7), 1343-1353.

Johannessen, E., Ovell, L., Eikum, A.S., Ek, M., Junestedt, C., 2008. Funksjonskontroll av renseanlegg i spredt bebyggelse i Morsa-vassdraget. COWI/IVL Report, COW Fredrikstad Norway, $93 \mathrm{p}$ (In Norwegian).

Kraft, P.I., 2002. Biological Filters - Design and Treatment Effect (Biologiske filtre utforming og renseeffekt). Jordforsk Report 33/02. Ås, Norway (in Norwegian).

Krogstad, T., Øgaard, A.F., Kristoffersen, A.Ø., 2008. New P recommendation for grass and cereals in Norwegian agriculture. NJF Report 4 (4), 42 46.

Kvarnström, E.M., Morel, C.A.L., Krogstad, T., 2004. Plant-availability of phosphorus in filter substrate derived from small-scale wastewater treatment system. Ecol. Eng. 22 (1), 1-15.

Lance, J.C., 1972. Nitrogen removal by soil mechanisms. J. Water Poll. Control Fed. 44 (7), 1352-1361.

Mitsch, W.J., Zhang, L., Anderson, C.J., Altor, A.E., Hernández, M.E., 2005. Creating riverine wetlands: ecological succession, nutrient retention, and pulsing effects. Ecol. Eng. 25 (5), 510-527.

Mæhlum, T., Jenssen, P.D., 2002. Design and performance of integrated subsurface flow wetlands in a cold climate. In: Mander, Ü., Jenssen, P.D. (Eds.), Constructed 
Wetlands for Wastewater Treatment in Cold Climates. Advances in Ecological Sciences, vol. 11. WIT Press, pp. 69-86.

Nilsson, P., 1990. Infiltration of Wastewater - An Applied Study on Treatment of Wastewater by Soil Infiltration. Rapport 1002, Dept. Environ. Eng., Univ. Lund, Sweden.

Ntengwe, F.W., 2005. The cost benefit and efficiency of waste water treatment using domestic ponds-the ultimate solution in Southern Africa. J. Phys. Chem. Earth Parts A/B/C 30 (11-16), 735-743.

Paruch, A.M., Krogstad, T., Jenssen, P.D., 2007. Application of used wetland filter media in agriculture - control of heavy metal contents and faecal contamination. Ecohydrol. Hydrobiol. 7 (3-4), 243-253.

Paulsrud, B., Gjerde, B., Lundar, A., 2004. Full scale validation of helminth ova (Ascaris suum) inactivation by different sludge treatment processes. Water Sci. Technol. 49 (10), 139-146.

Paulsrud, B., Lundar, A., Tharaldsen, J., Zerihun, M.A., 2006. "Hygienisering av avløpsslam. Hygienisation of sewage sludge” (in Norwegian). Aquateam Report, 05-016, Oslo, Norway.

Pierzo, V., Pierlot, E., Le Broc, F., Roussel, S., Simonart, T., 2004. Feasibility of Horizontal Standards for the enumeration of Viable Helminth Ova in Sludge, Soil Treated Biowastes. HORIZONTAL - WP3: Final Desk Study Report. Institut Pasteur de Lille, France.

Refsgaard, K. Etnier, C., 1998 Natural Treatment Systems for Wastewater Treatment in Rural Areas: Economic and Environmental Evaluation for Rural Municipalities, Households and Farms. NILF-rapport 1998: 4, NILF, Oslo, Norway (in Norwegian).

Sartoris, J.J., Thullen, J.S., Barber, L.B., Salas, D.E., 2000. Investigation on nitrogen transformations in a southern California constructed wastewater treatment wetland. Ecol. Eng. 14 (1-2), 49-65.
Schijven, J.F., Hassanizadeh, S.M., 2000. Removal of viruses by soil passage: overview of modeling, processes and parameters. Review article. Environ. Sci. Technol. 30 (1), 49-127.

Seghezzo, L., Zeeman, G., van Liel, J.B., Hamelers, H.V.M., Lettinga, G., 1998. A review: the anaerobic treatment of sewage in UASB and EGSB reactors. Bioresour. Technol. 65 (3), 175-190.

SEPA, 2003. Swedish Environmental Protection Agency. Strategy for Phosphorus Recycling from Wastewater (Aktionsplan för återföring av fosfor ur avlopp). Report 5214, Stockholm, Sweden (in Swedish).

SFS 3015, 1985. Veden fekaalisten streptokokkien lukumäärän selvitys putkimenetelmällä. Water Quality. Detection and Enumeration of Fecal Streptococci by Enrichment in a Liquid Medium.

Søvik, A.K., Kløve, B., 2005. Phosphorus retention processes in shell sand filter systems treating municipal wastewater. Ecol. Eng. 25 (2), 168-182.

Thullen, J.S., Sartoris, J.J., Nelson, S.M., 2005. Managing vegetation in surface-flow wastewater-treatment wetlands for optimal treatment performance. Ecol. Eng. 25 (5), 583-593.

Vymazal, J., 2005. Horizontal sub-surface flow and hybrid constructed wetlands systems for wastewater treatment. Ecol. Eng. 25 (5), 478-490.

Yri, A., Hensel, G. R., Aasen, R., Mæhlum, T., 2007. Undersøkelse av mindre avløpsanlegg i normal drift. Bioforsk Rapport, vol. 2, nr. 151/06, 37 p. (in Norwegian).

Zhu, T., Mæhlum, T., Jenssen, P.D., Krogstad, T., 2003. Phosphorus sorption characteristics of a light-weight aggregate. Water Sci. Technol. 48 (5), 93-100.

Zhu, T., 1998. Phosphorus and Nitrogen Removal in Light-weight Aggregate (LWA) Constructed Wetlands and Intermittent Filter Systems. Ph.D. Theses 1997:16. The Agricultural University of Norway. 